\title{
ECONOMIC-ENVIRONMENTAL IMPACTS OF SHELTERBELTS IN SASKATCHEWAN, CANADA
}

\author{
SUREN KULSHRESHTHA, REDWAN AHMAD, KEN BELCHER \& LINDSEY RUDD \\ Department of Agricultural and Resource Economics, University of Saskatchewan, Canada
}

\begin{abstract}
In the beginning of the 20th century, due to semi-arid climate conditions, planting trees was recommended to protect buildings, crops and animals from wind and extreme temperatures. Over a period of time, technology of production has changed and landowners see little private benefits from maintaining shelterbelts. A growing trend of shelterbelt removal, particularly from field and livestock areas, has been observed. In the future, perhaps continuation of such a trend seems eminent. Although landowners' decision to remove shelterbelts could be justified on economic grounds, environmental damage, in terms of increased greenhouse gas emissions, could be serious. Government policy is needed to provide incentives to landowners to maintain shelterbelts.
\end{abstract}

Keywords: shelterbelts, Saskatchewan, carbon sequestration, private benefits, removal.

\section{INTRODUCTION}

Linear tree planting, a feature called shelterbelts, has a history going back to 1870 s. Shelterbelts are trees of various sizes typically planted on Prairie farms for wind protection, and other benefits. They provide a variety of positive impacts including environmental goods and services within agricultural landscapes. In fact, when the North-West province was transferred to the Dominion of Canada, the federal government undertook steps to enhance settlement of the region. The government felt that a tree planting program would enhance the landscape, produce more rainfall, and aid in successful agriculture [1].

At the same time eastern Canada was going through large scale deforestation (driven by development of cities, towns and related infrastructure), and there was a concern that there might be a shortage of lumber. By 1901, the Forestry Branch of the Department of the Interior began propagating plant material at Brandon, Manitoba, and Indian Head, Saskatchewan, and in 1902 started providing trees to landowners free of charge [2]. During 1901 to 2002, some 576 million tree seedlings have been provided to landowners through the Canadian government's prairie shelterbelt centre located in Indian Head, Saskatchewan [1]. They have distributed 4 to 12 million tree seedlings per annum, to some ten to twelve thousand landowners in the three Prairie Provinces. After analysing digital air photos collected between 2007 and 2012, Piwowar et al. [3] estimated that in Saskatchewan alone, 51,653 km of shelterbelts have been established in the agricultural region. Although planning of shelterbelts has been popular at the beginning of the 20th century, but such trends have not continued in the recent past.

In the context of climate change reducing greenhouse gas (GHG) emissions has been accepted to be an important avenue. Shelterbelts can reduce these emissions through carbon (C) sequestration in trees, understory, as well in the adjoining soil. However, recent past trends in Saskatchewan suggest that more and more landowners are removing these trees and thus creating an environmental externality. These issues need further investigation. 


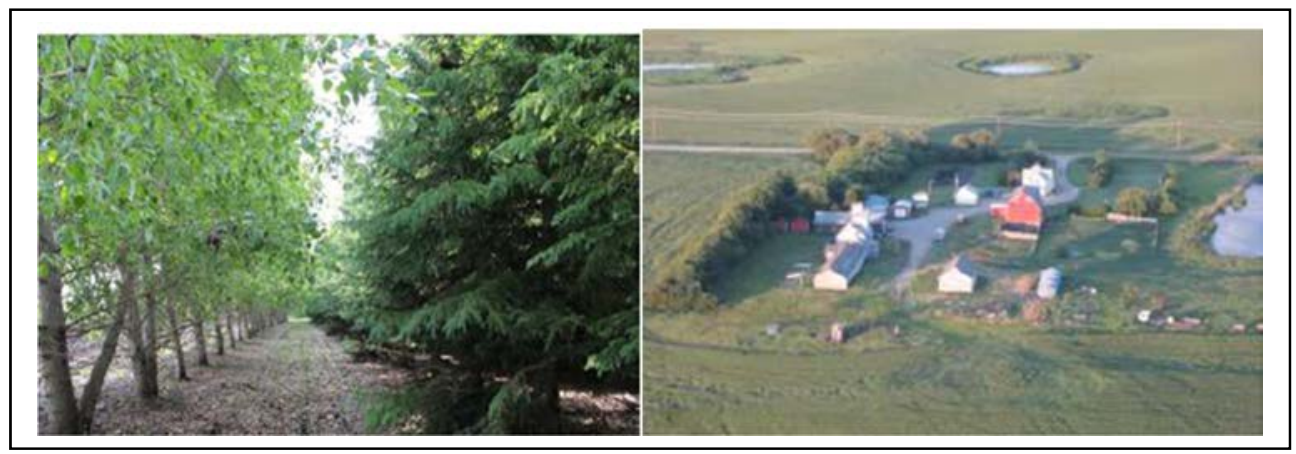

Figure 1: Field and farmyard shelterbelts.

\section{OBJECTIVES OF THE STUDY}

It is necessary for policy making purposes that reasons for removal and retention of shelterbelts are investigated. Thus, the major objective of this study is to investigate these factors both for those landowners who have removed shelterbelts on their farms as well those who have decided to retain them. The major hypothesis of the study is that these removal decisions are economically motivated without taking into account any environmental externalities. Thus, a secondary objective of the study is to review the economics and environmental implications of retention or removal of shelterbelts in Saskatchewan.

\section{METHODOLOGY}

Information for this study was collected through a survey of landowners in Saskatchewan. A total of 67 landowners were contacted during the summer of 2017. In addition, a previous survey undertaken in 2013 was also used which included 61 landowners. In addition, review of previous studies was also undertaken for shelterbelt benefits. To identify factors affecting the landowners' decisions to remove / retain, a logistic function was estimated, supplemented with an economic simulation model to examine economics of retaining shelterbelts on farms.

\section{RESULTS}

\subsection{Shelterbelts on Saskatchewan farms}

Shelterbelts are a common feature on Saskatchewan farms. They are linear arrangements of trees or shrubs. Often, and particularly around farmsteads, one observes several (usually 24) rows of such trees, shrubs or both. In fact, in a survey of famers in Saskatchewan, all landowners reported having shelterbelts surrounding their home (called farmstead shelterbelts). Shelterbelts planted in the province from 1888 to 2014 are predominantly two types - farmyard (57.6\%) and field or livestock yard (42.4\%) shelterbelts [1], [3]. Typical species planted are: Caragana, Green ash, Hybrid poplar, Manitoba maple, Scots pine, and White spruce. The last species is predominantly found in the higher latitudes.

In a sample of 61 landowners in 2013, only 21 (34\%) landowners had shelterbelts around their fields or livestock yards (Table 1). A similar situation was observed in 2017. Of the 67 landowners, only $12 \%$ had shelterbelts on the areas where livestock are kept. Small number of livestock farms with shelterbelts is perhaps indicative of the predominance of grain farming in the province. 
Table 1: $\quad$ Types of shelterbelts on Saskatchewan farms by type of shelterbelts, 2013 and 2017.

\begin{tabular}{|l|c|c|}
\hline \multirow{2}{*}{\multicolumn{1}{|c|}{ Type of shelterbelt }} & \multicolumn{2}{c|}{$\begin{array}{c}\text { No. of farms } \\
\text { reporting }\end{array}$} \\
\cline { 2 - 3 } & $\mathbf{2 0 1 3}$ & $\mathbf{2 0 1 7}$ \\
\hline Farmstead shelterbelts & 61 & 66 \\
\hline Crop field shelterbelts & 18 & 28 \\
\hline Livestock yard shelterbelts & 5 & 5 \\
\hline Other shelterbelts* & 6 & 2 \\
\hline Both crop field and livestock yard shelterbelts & 2 & 3 \\
\hline Both crop field and other shelterbelts & 3 & 2 \\
\hline All crop field, livestock yard, and other shelterbelts & 8 & 33 \\
\hline No crop field or livestock yard shelterbelts & 20 & 37 \\
\hline Total respondents** & 61 & 67 \\
\hline
\end{tabular}

* Include riparian, natural buffer type shelterbelts.

** Numbers would not add up to the total since some farms have more than one type of shelterbelts.

\subsection{Private and social benefits from shelterbelts}

Economic value of a natural asset can be measured as a sum of all benefits that are provided through their ecosystem functions. According to the Millennium Ecosystem Assessment (MEA) [4], ecosystems can provide four types of services to society: Supporting services (services necessary for all other ecosystem services), Provisioning services (products obtained from ecosystems), Regulating services (regulation of ecosystems), and Cultural services (non-material benefits obtained from ecosystems). These services provide benefits which accrue to both the landowners as well as to the public (society) at large through different pathways (Table 2).

\subsubsection{Private benefits}

Landowners benefits from shelterbelts in a variety of ways. Many of these cannot be estimated due to lack of information and data for the Saskatchewan conditions. Some of the positive impacts include soil stabilization and erosion mitigation resulting in soil fertility and eventually higher crop yields on farms especially in areas close to the shelterbelt [5]. Energy conservation from the shelterbelts around the farmstead is one of the measured private benefits of shelterbelts, estimated to be $\$ 60-\$ 443$ million (in 2018 prices) for the three Prairie Provinces (based on Kulshreshtha et al. [6] estimates).

\subsubsection{Public (societal) benefits}

Society as a whole also reaps benefits from the farm shelterbelts with one of the major benefit in terms of climate regulation through carbon sequestered in the trees, understorey and soil. Social benefits from reduced off-farm costs provided by shelterbelts include water quality improvements, increased biodiversity, and improved energy conservation. Kulshreshtha et al. [6] estimated this benefit to be from $\$ 96$ to $\$ 741$ million (in 2018 prices). Thus, shelterbelts are important to society as well as to landowners, but overall it appears society gains more by having these on their farms. 
Table 2: Conceptual accounting for private and society economic value of shelterbelts using ecosystem services pathways.

\begin{tabular}{|c|c|c|c|c|}
\hline \multirow{2}{*}{$\begin{array}{l}\text { Ecosystem } \\
\text { Services }\end{array}$} & \multirow[t]{2}{*}{ Pathways } & \multirow[t]{2}{*}{ Benefits from shelterbelts } & \multicolumn{2}{|c|}{ Type of benefit } \\
\hline & & & Private & Public \\
\hline $\begin{array}{l}\text { Supporting } \\
\text { services }\end{array}$ & Soil & $\begin{array}{l}\text { Soil formation, fertility, \& stabilization: (1) } \\
\text { Reduced soil erosion; (2) Shoreline protection; }\end{array}$ & $\mathrm{X}$ & $\begin{array}{l}X \\
X\end{array}$ \\
\hline \multirow[t]{2}{*}{$\begin{array}{l}\text { Provisioning } \\
\text { services }\end{array}$} & $\begin{array}{l}\text { Socio- } \\
\text { economic }\end{array}$ & $\begin{array}{l}\text { Food: (1) Increase in yields; (2) Feeding efficiency } \\
\text { of farm animals; (3) Reduced death loss of young } \\
\text { animals; (4) Harvest of berries and mushrooms; } \\
\text { Non-food: (1) Ornamental resources; (2) Improved } \\
\text { aesthetics and related amenities; (3) Fuelwood; (4) } \\
\text { Energy conservation; (5) Improved transportation } \\
\text { infrastructure and traffic related benefits; }\end{array}$ & $\mathrm{X}$ & $\mathrm{X}$ \\
\hline & Biota & Genetic resources & & $\mathrm{X}$ \\
\hline \multirow[t]{3}{*}{$\begin{array}{l}\text { Regulating } \\
\text { services }\end{array}$} & Air & $\begin{array}{l}\text { (1) Climate regulation through reduced greenhouse } \\
\text { gas emissions; (2) Reduced odor from animal } \\
\text { production sites; (3) Reduced pesticide drifts } \\
\text { affecting water quality; }\end{array}$ & $\mathrm{X}$ & $\mathrm{X}$ \\
\hline & Water & $\begin{array}{l}\text { (1) Improved groundwater quality through filtering } \\
\text { function; (2) Improved floodplain management; (3) } \\
\text { Improved wastewater management; }\end{array}$ & & $\mathrm{X}$ \\
\hline & Biota & $\begin{array}{l}\text { (1) Pollination; (2) Increased biodiversity; (3) } \\
\text { Improved wildlife habitats; }\end{array}$ & & $\mathrm{X}$ \\
\hline $\begin{array}{l}\text { Cultural } \\
\text { services }\end{array}$ & Biota & $\begin{array}{l}\text { (1) Improved wildlife-based recreation; (2) } \\
\text { Improved aesthetics and related health effects; (3) } \\
\text { Educational benefits; }\end{array}$ & & $\begin{array}{l}\mathrm{X} \\
\mathrm{X}\end{array}$ \\
\hline
\end{tabular}

\subsection{State of shelterbelt removal on Saskatchewan farms}

\subsubsection{Landowners choice of removing shelterbelts on farms}

In spite of several benefits from shelterbelts to its owner as well as the society as a whole, as noted above, some of the landowners have removed them. In a study, Rempel et al. [7] found $40 \%$ of the farm operators (24 out of 61 operators) in Saskatchewan removed shelterbelts from their operations. Since more details on these removals were not available, another survey was undertaken in 2017. This survey data showed that 30 out of 65 landowners (or $46.2 \%$ of total) removed shelterbelts from their operations.

Landowners removed their shelterbelts either completely from the fields (or livestock areas or farmstead) or only partially. In this survey, about $33.8 \%$ of the operators removed their shelterbelts partially (such as removal of few tress or one row or segment on a given parcel) (Table 3). However, another $12.4 \%$ of them removed their shelterbelts entirely. The remaining $53.8 \%$ of landowners did not remove their shelterbelts.

Many of these shelterbelts that were removed were older (average age of trees was 31.6 years and 32.6 years for farmyard and field shelterbelts, respectively). Deciduous tree species including Elms and Hybrid Poplar, and Evergreens were mostly removed in farmyard shelterbelts removal, whereas shrub species such as Caragana and Green Ash were removed from field shelterbelts.

\subsubsection{Reasons for removal}

The original context, in which shelterbelts were planted and maintained, has changed significantly due to changes in agricultural production methods. The new context results in a number of reasons for removing their shelterbelts. 
Table 3: Characteristics of shelterbelts (SB) removal, 2017.

\begin{tabular}{|c|c|c|c|c|c|}
\hline $\begin{array}{l}\text { Percent of } \\
\text { total farms } \\
\text { removing SB }\end{array}$ & $\begin{array}{l}\text { Natureof } \\
\text { removal }\end{array}$ & $\begin{array}{l}\text { Types of SB } \\
\text { removed }\end{array}$ & $\begin{array}{c}\text { Average } \\
\text { proportion of SB } \\
\text { removed }(\%)\end{array}$ & $\begin{array}{l}\text { Types of species } \\
\text { removed } \\
\text { (mostly) }\end{array}$ & $\begin{array}{l}\text { Average age } \\
\text { of species } \\
\text { removed }\end{array}$ \\
\hline $6.2 \%$ & Fully & \multirow[b]{2}{*}{ Farmyard } & \multirow[b]{2}{*}{$39 \%$} & \multirow{2}{*}{$\begin{array}{l}\text { Elms, Hybrid } \\
\text { Poplar, } \\
\text { Evergreens } \\
\end{array}$} & \multirow[b]{2}{*}{31.6 years } \\
\hline $18.4 \%$ & Partially & & & & \\
\hline $6.2 \%$ & Fully & \multirow{2}{*}{ Field } & \multirow{2}{*}{$60 \%$} & Caragana, & \multirow{2}{*}{32.6 years } \\
\hline $15.4 \%$ & Partially & & & Green Ash & \\
\hline
\end{tabular}

In this study, the predominant reason for removal was shelterbelt damage due to storms, floods, chemical hazards, fire hazards and other natural reasons (such as expiry of life expectance).

This reason was reported by $40 \%$ of the all landowners undertaking removal. About $23.3 \%$ of the respondents mentioned more site-specific reasons for removal, including building development in the farmyard, accommodating larger equipment, and allowing space for power lines.

Landowners who removed shelterbelts provided economic reasons for their action. In particular, with current higher crop prices (relative to the period when these shelterbelts were planted), they see the land occupied by the shelterbelts as a major loss of revenue. The other reason provided for their removal was changes in technology. There is a trend in North America for farm machinery and equipment to be larger, necessitated by shorter growing season (particularly for seeding and harvest operations) and growing size of farms. With larger machinery the efficiency of inputs use (such as fertilizer or herbicides) is impacted unless the field with shelterbelts has room for the equipment to make a proper turn. Under these conditions, either some areas are skipped or applied double [8]-[10]. Both of these factors increase production costs on the farm. In the case of field shelterbelts, $16.7 \%$ of the operators found them inconvenient for these reasons. In fact, in the 2013 survey, about $42 \%$ of landowners stated this to be main reason for removal of shelterbelts (Fig. 2). Another $13.3 \%$ of the respondents argued that with advances in agricultural production system, from tillage system to zero or minimal tillage system, soil erosion problem is reduced, making shelterbelts somewhat redundant [8], [11]. Those who maintained the shelterbelts, snow capture and protection from wind / dust were their major consideration (Table 5).

Table 4: Reasons provided by landowners for shelterbelts removal, 2017.

\begin{tabular}{|l|l|c|}
\hline \multirow{2}{*}{$\begin{array}{c}\text { Type of shelterbelts } \\
\text { removed }\end{array}$} & \multicolumn{2}{|c|}{ Reasons for removal } \\
\cline { 2 - 3 } & Types of reason & Frequency in \% \\
\hline \multirow{5}{*}{ Farmyard } & Damaged & 30.0 \\
\cline { 2 - 3 } & Relocation & 3.3 \\
\cline { 2 - 3 } & Replaced with other species & 3.3 \\
\cline { 2 - 3 } & Room for other needs & 16.7 \\
\hline \multirow{5}{*}{ Field } & Damaged & 10.0 \\
\cline { 2 - 3 } & To increase cropland & 6.7 \\
\cline { 2 - 3 } & Inconvenience & 16.7 \\
\cline { 2 - 3 } & Redundant & 6.7 \\
\cline { 2 - 3 } & Room for other needs & 6.6 \\
\hline
\end{tabular}




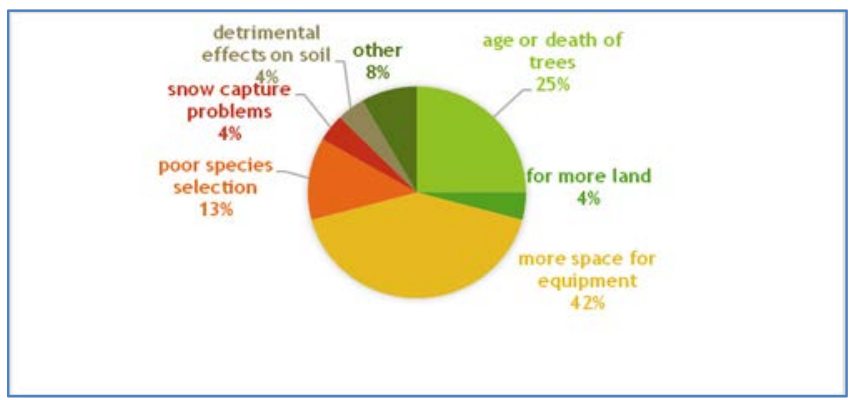

Figure 2: Produces response for reasons leading to removal of shelterbelts. (Source: Remple [12].)

Table 5: Landowners reasons for maintaining/removing shelterbelts.

\begin{tabular}{|l|l|l|l|}
\hline \multicolumn{2}{|c|}{2013 survey } & \multicolumn{2}{c|}{2017 survey } \\
\hline \multicolumn{2}{|c|}{ Landowners not removing shelterbelts } & \multicolumn{2}{c|}{ Landowners not removing shelterbelts } \\
\hline Favorable & Not-favorable & Favorable & Not-favorable \\
\hline Snow capture & Labor requirements & Wind/ dust protection & $\begin{array}{l}\text { Difficulties with planting/ } \\
\text { growth success* }\end{array}$ \\
\hline $\begin{array}{l}\text { Beauty in the } \\
\text { landscape }\end{array}$ & Maintenance cost & Snow capture & $\begin{array}{l}\text { Field shelterbelts hinders or } \\
\text { does not impact the success } \\
\text { of the crops** }\end{array}$ \\
\hline $\begin{array}{l}\text { Protection from } \\
\text { wind }\end{array}$ & $\begin{array}{l}\text { Spread of insects or } \\
\text { diseases by shelterbelts }\end{array}$ & Aesthetic landscape & $\begin{array}{l}\text { In the way of larger } \\
\text { equipment }\end{array}$ \\
\hline \multicolumn{1}{|c|}{ Landowners removing shelterbelts } & \multicolumn{1}{|c|}{ Landowners removing shelterbelts } \\
\hline $\begin{array}{l}\text { Protection for } \\
\text { my home }\end{array}$ & Labor requirements & Wind/ dust protection & Damaged/dead trees \\
\hline $\begin{array}{l}\text { Protection form } \\
\text { blowing snow } \\
\text { and wind }\end{array}$ & $\begin{array}{l}\text { In the way of large } \\
\text { equipment }\end{array}$ & $\begin{array}{l}\text { Aesthetic/ snow } \\
\text { capture ranked the } \\
\text { same }\end{array}$ & $\begin{array}{l}\text { In the way of larger } \\
\text { equipment }\end{array}$ \\
\hline $\begin{array}{l}\text { Reduced soil } \\
\text { erosion }\end{array}$ & Land out of production & $\begin{array}{l}\text { Habitat for wildlife/ } \\
\text { birds }\end{array}$ & $\begin{array}{l}\text { Obstacle for infrastructure } \\
\text { (housing, fence line, other } \\
\text { farm buildings) }\end{array}$ \\
\hline
\end{tabular}

* Common theme (responses included: difficulty growing trees in this province, improper planting design hindering success of shelterbelts, wish trees would grow faster).

** Either harms the crop success rate (e.g., stealing moisture from crops) or does not have any perceived benefit (specifically regarding the introduction of direct seeding).

\subsubsection{Trend in shelterbelt removal}

Based on the two surveys, trends were noted in the number of landowners who have removed shelterbelts on their farm (Fig. 3). The left chart (2013 survey) shows a very definite trend in number of landowners while the right hand chart (based on the 2017 survey) shows some moderation, although even now about $8 \%$ of landowners have been engaged in such removal. 


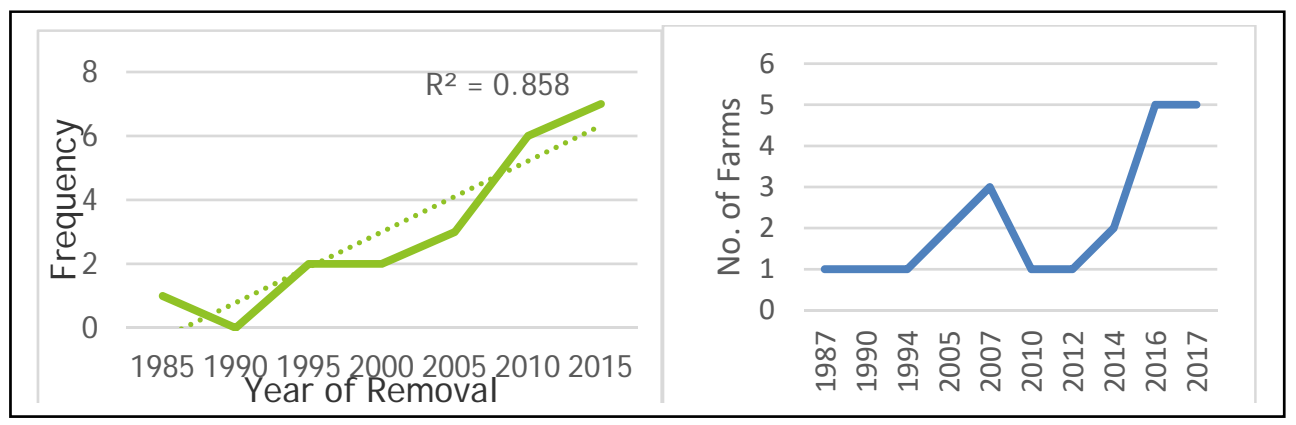

Figure 3: Trends in shelterbelt removal by Saskatchewan landowners. (Left-hand chart source: Remple [12].)

\subsection{Landowners' characteristics affecting removal of shelterbelts on farms}

Although landowners did provide their respective reasons for shelterbelt removal, for policy formulation purposes, more information on "who these landowners are?" is needed. In other words, characteristics of landowners who are removing and who are not removing shelterbelts could be considered to be an important factor in deciding the major target group for policies. The 65 landowners (two cases were excluded due to incomplete information) in the 2017 survey were selected for this analysis. A logistic model was hypothesized with producer characteristics as independent variables. The left-hand side variable was a limited dependent variable (binary variable) assigned a value of 1 if the producer removed the shelterbelts totally or partially (over $50 \%$ of the total), and 0 if the producer retained the shelterbelts or if removed, the magnitude was less than $50 \%$.

Five characteristics were hypothesized to affect the decision to undertake removal of shelterbelts: Age of the landowner (hypothesized to have a negative relationship); Sex of the producer $(\mathrm{M} / \mathrm{F})$; Years of experience with farming, measured in years on the farm; Education level, measured as years of schooling; Farm size (in ha), and whether or not the producer has a succession plan for the farm (coded as a binary variable with a value of 1 if the producer had a plan, 0 otherwise). The farm size variable showed some non-linearities and therefore was converted into logarithmic form. The estimated coefficients are shown in Table 6.

Table 6: Results of factors affecting removal of shelterbelts on Saskatchewan farms, 2017.

\begin{tabular}{|l|l|c|}
\hline \multicolumn{1}{|c|}{ Particulars } & \multicolumn{1}{|c|}{ Description of variable } & $\begin{array}{c}\text { Estimated coefficient } \\
\text { and (probability) }\end{array}$ \\
\hline Age & Year & $-0.022(0.208)$ \\
\hline Gender & Binary (=1 if male, 0 if female) & $0.380(0.302)$ \\
\hline Education (in year) & No. of years & $0.145(0.047) *$ \\
\hline Succession plan & Binary (=1 if producer has a succession plan, 0 for no) & $-1.336(0.003)^{*} *$ \\
\hline Log of farm size & Size in ha & $0.073(0.477)$ \\
\hline Constant & & $-0.725(0.647)$ \\
\hline Chi-Square & & 16.06 \\
\hline Pseudo R ${ }^{2}$ & & 0.196 \\
\hline Log-likelihood ratio & & -32.85 \\
\hline Sample size $(\mathrm{n})$ & & 62 \\
\hline
\end{tabular}

*Significantly different from zero at 5\% level; ** Significantly different from zero at $1 \%$ level. 
This analysis reveals that the significant determining factors for the decision to remove shelterbelts are: landowners' education level (measured as years of schooling) and whether they have a succession plan for their farm to their children or grandchildren. Other factors, though statistically insignificant but may have implications, are landowners' age as well as size of their farm. Younger landowners are more educated, and search for more advanced technologies and much of this new equipment is large in order to handle larger sized farms. In addition, many landowners now utilize zero or minimal tillage system, which reduces the incidence of soil erosion. They find shelterbelts causing a barrier in manoeuvring large sized equipment. At the same time the land occupied by the shelterbelts is lost for crop production, and thus reduces returns from production. However, the older landowners, who have experienced previous periods of prolonged droughts (in 1930s, 1960s and 1980s), are more inclined to retain shelterbelts on their farm. Results of the statistical analysis support these observations.

\subsection{Economics of shelterbelts for landowners}

Since some of the drivers for maintaining and removing shelterbelts on farms were economic in nature, further analysis of the economics of maintaining shelterbelt on a crop field or a livestock area was needed. Two simulation models were developed, one for grain operations, and another for mixed livestock, pastures and grain farms. A discount rate of 5\% was used. Since economics of shelterbelts may differ from region to region, three models, one for each soil zone (Brown, Dark Brown, and Black soil zone), were developed. Secondary data on size, crop mix, and cultural practices were used as well as field size and location of shelterbelts within the field. Accounting stance selected was that of private (landowner).

\subsubsection{Grain farms}

Estimation of net returns to producers over the life of the shelterbelt (assumed to be 50 years) was done using a representative farm simulation model. The farm produced crops (using average crop mix for the soil zone) for market sales. Cost of planting and maintenance was included in the cost along with improvement in the yield of crops. Crop yield differences were estimated in response to distance from the shelterbelts. According to Kort [5], some grain crops and forages react positively to shelterbelt proximity, partly because of rich soil organic matter and shelter from wind and other natural events that may stress the crops. When land lost to production and increased yields of various crops are factored in, the farms located in the Brown and Dark Brown soil zones showed positive net returns, while those in the Black soil zone had negative net returns (due to small change in yields). When these values were converted on per unit of land, returns from keeping the shelterbelts were very low (Table 7). This is perhaps consistent with the landowners' impression that having shelterbelts on crop fields is not economically desirable.

\subsubsection{Livestock farms}

A similar simulation model was developed for a mixed crop-livestock farm. The crops on this farm were those that provided forage or feed grains for the cattle, in addition to pastures. Any excess feed grains was sold on the market. Unfortunately data on feeding efficiency improvement with shelterbelts were not available. Thus the model only included increased production of feed grains forages, and improved pasture resulting from the shelterbelts. Although net gains were positive, the amounts were relatively small, indicating that such shelterbelts have little private economic value, but impose limited economic costs. 
Table 7: Total Net present value of shelterbelts on crop and livestock farms, by soil zone, 2015 .

\begin{tabular}{|l|c|c|}
\hline \multicolumn{1}{|c|}{ Soil zone } & $\begin{array}{c}\text { Net present value } \\
\text { in thousand \$ }\end{array}$ & $\begin{array}{c}\text { Value per annum } \\
\text { in \$ }\end{array}$ \\
\hline \multicolumn{2}{|c|}{ Crop farm } & Per ha \\
\hline Brown & $\$ 105.2$ & $\$ 2.00$ \\
\hline Dark Brown & $\$ 161.9$ & $\$ 3.06$ \\
\hline Black & $-\$ 195.6$ & $-\$ 9.69$ \\
\hline \multicolumn{2}{|c|}{ Livestock farm } & Per cow-calf pair \\
\hline Brown & $\$ 46.6$ & 2.64 \\
\hline Dark Brown & $\$ 49.2$ & 2.78 \\
\hline Black & $\$ 49.5$ & 2.80 \\
\hline
\end{tabular}

Table 8: Level of carbon sequestered by shelterbelts by type. (Source: Amichev et al. [13].)

\begin{tabular}{|l|l|c|c|}
\hline \multirow{2}{*}{$\begin{array}{l}\text { Type of } \\
\text { shelterbelt }\end{array}$} & \multirow{2}{*}{ Name of the plant } & \multicolumn{2}{|c|}{$\begin{array}{l}\text { Amount of carbon sequestered } \\
\text { in mega grams per year per ha }\end{array}$} \\
\cline { 3 - 4 } & & Low value & High value \\
\hline Tree & Hybrid poplar & 3.29 & 5.18 \\
\hline Tree & Scots pine & 1.44 & 3.26 \\
\hline Tree & White spruce & 2.24 & 4.13 \\
\hline Tree & Green ash & 2.02 & 3.92 \\
\hline Tree & Manitoba maple & 2.80 & 5.26 \\
\hline Shrub & Caragana & 1.31 & 2.67 \\
\hline
\end{tabular}

\subsection{Environmental impacts of shelterbelt removal}

In addition to economic benefits, shelterbelts also provide several environmental benefits to the society. Some of these were listed in Table 1. Unfortunately, monetary value of these benefits in the context of shelterbelts has not been estimated. One of the most important ecosystem value from shelterbelts are their capacity to sequester C. Amichev et al. [13] have estimated that at maturity, these trees can sequester a large amount of carbon. For example, a hybrid poplar can sequester 3 to $5 \mathrm{t}$ of $\mathrm{C}$, whereas a Caragana shrub can store only 1.3 to $2.7 \mathrm{t} \mathrm{C}$ (Table 7). However, the amount of $\mathrm{C}$ stored in the younger trees would be lower but eventually the amount would reach the levels shown in the table 8 . If one uses the 2022 Canada-made price of $\$ 50$ per t of $C$, a hybrid poplar tree is worth $\$ 150-250$ to the society. Unfortunately, this value is not internalized in the decision of the landowners since at present they do not receive any compensation for the stored or sequestered carbon.

\section{CONCLUSIONS}

Continued removal of shelterbelts or their maintenance and establishment by landowners depends much on the government policy. Pannell [14] has suggested that the public policy intervention is justified if benefits to society exceed that of the private parties (landowners). Such policies may be in the form of incentive or penalties. One of the major obstacles in retaining/maintaining shelterbelts is the opportunity cost of the land occupied by them. Unless there is some revenue generated for these lands, landowners see the shelterbelts as a counter-productive measure. Policies have to be developed to compensate the producer for the loss of this revenue. The second focus of attention of public policy should be to address the high cost of establishment of new shelterbelts. The era of free seedlings distributed by a 
federal government agency is over. This is a major disincentive to landowners and should be addressed by a policy to encourage landowners to plant and maintain shelterbelts on their farms. Development of new tree and shrub varieties that can provide an increase in crop yields may also be considered as a part of the policy development.

\section{ACKNOWLEDGEMENTS}

Authors are thankful to the Agriculture and Agri-Food Canada for providing funding for this project under the Agricultural Greenhouse Gas Program (AGGP). We are also thankful to Nanyan Feng to develop the simulation model for estimating the farm level economics of shelterbelts, and to Janell Rempel for undertaking the survey of landowners in 2013.

\section{REFERENCES}

[1] Kulshreshtha, S., Van Rees, K., Hesseln, H., Johnston, M. \& Kort, J., Issues in agroforestry development on the Canadian Prairies, Handbook on Agroforestry Management Practices and Environmental Impacts, ed. R. Kellimore, Nova Science Publishers, Inc.,: New York, pp. 91-127, 2010.

[2] Howe, J.A.G., One hundred years of prairie forestry. Prairie Forum, 11, pp. 243-251, 1986.

[3] Piwowar, J.M., Amichev, B.Y. \& Rees, K.C.V., The Saskatchewan shelterbelt inventory. Cdn. J. Soil Sc., 97(3), pp. 433-438, 2016.

[4] MEA (Millennium Ecosystem Assessment). Ecosystems and Human Wellbeing - A Framework for Assessment, Island Press: London, 2003.

[5] Kort, J., Benefits of windbreaks to field and forage crops. Agr. Ecosyst. Environ., 22/23, pp. 165-190, 1988.

[6] Kulshreshtha, S., Knopf, E., Kort, J. \& Grimard. J., The Canadian shelterbelt program: Economic valuation of benefits. Evaluating Agri-Environmental Policies, OECD (Organization for Economic Cooperation and Development): Paris, 2005.

[7] Rempel, J., Kulshreshtha, S., van Rees, K. \& Amichev, B., Factors that influence shelterbelt retention and removal in Prairie agriculture as identified by Saskatchewan producers. Soils and Crops 2014, University of Saskatchewan: Saskatoon, 2014.

[8] Kulshreshtha, S. \& Rempel, J., Shelterbelts on Saskatchewan farms: an asset or nuisance. Climate Change and Forest Ecosystems, eds S. Lac, \& M. McHenry, Nova Publishers: New York, pp. 37-54, 2014.

[9] Rempel, J.C., Kulshreshtha, S.N., Amichev, B.Y. \& van Rees, K.C., Costs and benefits of shelterbelts: A review of producers' perceptions and mind map analyses for Saskatchewan, Canada. Cdn. J. Soil Sc., 97(3), pp. 341-352, 2016.

[10] Taylor, J., Private benefits of field shelterbelts in the Saskatchewan brown soil zone. Undergraduate thesis, BPBE 492, University of Saskatchewan, Saskatoon, Canada, 2010.

[11] Casement, B. \& Timmermans, J., Field Shelterbelts for Soil Conservation, Alberta Agriculture and Food: Edmonton, Canada, 2007.

[12] Remple, J.C., Costs, benefits, and barriers to the adoption and retention of shelterbelts in Prairie Saskatchewan Producers. MES thesis, University of Saskatchewan, Saskatoon, Canada.

[13] Amichev, B., Bentham, M., Kulshreshtha, S., Laroque, C., Piowar, J. \& Van Rees, K., Carbon sequestration and growth of six common tree and shrub shelterbelts in Saskatchewan, Canada. Cdn. J. Soil Sc., 92, pp. 368-381, 2016.

[14] Pannell, D.J., Public benefits, private benefits, and policy mechanism choice for land use change for environmental benefits. Land Econ., 84(2), pp. 225-240, 2008. 